\title{
The Opinions of Mothers of Children with Special Needs Regarding Inclusive Education
}

\author{
${ }^{1}$ Yildiz Technical University, Turkey \\ ${ }^{2}$ Ankara University, Turkey \\ Correspondence: Remziye Ceylan, Yildiz Technical University, Turkey.
}

Received: May 4, 2016 Accepted: May 11, $2016 \quad$ Online Published: July 4, 2016

doi:10.11114/jets.v4i9.1589 URL: http://dx.doi.org/10.11114/jets.v4i9.1589

\begin{abstract}
The aim of this study was to investigate the opinions of mothers who had children with special needs attending inclusive elementary schools regarding inclusive practice. With this purpose, 11 mothers with children attending the first, second and third grades of inclusive elementary schools affiliated to the Ministry of National Education in the Edirne province were interviewed. In this phenomenological study, the data collected through interviews was analyzed with content analysis. The results showed that the mothers were not adequately knowledgeable on the subject of inclusion. In the study, most of the mothers said that the similarities between the child with special needs and normally developing children were mostly physical, that the orthopedic impairment group could benefit more from inclusion, that adjustments were made in the child's seating in the educational environment and that during the course of inclusion they required educational support services most of all. In addition, most of the mothers experienced various difficulties in inclusive education concerning lessons, enrolling the child to school and class, and transportation of the child to and from the school.
\end{abstract}

Keywords: special education, inclusive education, inclusion, child with special needs, mothers' opinions

\section{Introduction}

Inclusive education, which is about according equal rights, is defined as placing children with disabilities to regular or general education classes for instruction by providing appropriate support (Lerner, 2000). In order to accomplish desirable results in the inclusion of children with disabilities, proper communication, cooperation and accord between classroom teachers, special education teachers, families and the sources of society must be ensured. The education of children with special needs, once regarded as the field of special educators, is now considered to be a shared responsibility requiring team work (Salend, 1998). In their study, Ben-Yehuda, Leyser and Last (2010) determined that teachers successful in increasing the social interaction of children with special needs acquainted themselves with the child's past and established meaningful and positive relationships with their families. Another study found that parent-school collaboration was an important factor affecting parents' opinions of the school (Elbaum, Blatz \& Rodriquez, 2016).

Families have as a significant role as teachers in the successful implementation of inclusive education. The limited quality and number of teachers and the lack of special educators to assist teachers render the support of the parents even more important. The results of a study demonstrated that the success of inclusive education is largely dependent on the ability of the families (Ahuja \& Sunish, 2013). The families should also have a positive attitude toward inclusion. The study by Gupta and Buwade (2013) reported that most of the parents of children with special needs had a positive attitude toward inclusion and that they supported the concept of inclusion. 65\% of the parents participating in the study said inclusion facilitated their children's adjustment to the real world and gave them a chance to participate and interact with their classmates. Various study with similar results showed that most of the mothers of children with special needs had a positive attitude toward inclusion and supported the concept of inclusion (Dimitrios, Georgia, Eleni, \& Asterios, 2008; Elzein, 2009). In addition, the study carried out by Kniveton (2004) revealed that the children who did not have a priority to be accepted to inclusive classrooms were the ones who required the most resources. Generally, mothers struggle for the placement of their children into general education classrooms so that they can have the same experiences and opportunities as other children and be raised as independent and contributing members of society. 
Another study reported that most of the parents of children in inclusive classrooms were more satisfied with the education provided to their children than the parents of children in special education schools (Gasteiger-Klicpera, Kilcpera, Gebhardt \& Schwab, 2013). However, some studies identified that mothers who had children with special needs were concerned whether their children would be socially accepted by their peers without disabilities in general education classrooms (Gupta \& Buwade, 2013; Ahuja \& Sunish, 2013). A study on inclusive education showed that nearly all the parents participating in the study needed to be informed. In addition, mothers stated that they did not know what was being taught at school and how to teach (Kargin, Acarlar \& Sucuoglu, 2003). Another study reported that the staff did not have adequate training and that the teachers disregarded the students' needs during inclusive practice. Furthermore, the interviews revealed that it was impossible for most of the schools to meet the psychological and clinical needs of children with physical disabilities and that inclusive education was a source of stress for all parties (Liewellyn, 2000). In addition, the study by Underwood (2010) reported that the parents thought that the school failed to entirely meet their children's needs. In another study on the problems families experienced in inclusion, it was determined that the problems families encountered and the difficulties the child experienced were dependent on the type of disability and that some children were accepted more easily by the rest of the staff for inclusion (Kniveton, 2004). Kasari, Freeman, Bauminger \& Alkin (1999) found that the type of disability influenced parental opinion concerning the ideal educational placement for the child.

Past research reveals that the mothers of children with special needs experience many problems in inclusive education because they are not informed and prepared for inclusion. Therefore, there is need to place more emphasis on the opinions of mothers who have children with special needs, as well as, to determine their opinions and to provide suggestions for quality preparatory studies on inclusive education. Furthermore, the determination of the opinions of mothers who have children with special needs is also important for its contribution to taking the necessary measures for achieving successful inclusion. In view of this perspective, the aim of this study was to investigate the opinions of mothers who had children with special needs attending the first, second and third grades of inclusive elementary schools in the Edirne province, regarding inclusive practice

\section{Method}

This study was conducted to determine the opinions of mothers who had children with special needs attending the first, second and third grades of inclusive elementary schools, regarding inclusive practice

\subsection{Identify Subsections}

The interview technique, which is a qualitative research method, was used in the study. The data was collected through semi-structured interviews. As the interview is a considerably powerful method used to identify people's perspectives, experiences, emotions and perceptions (Yildirim \& Simsek, 2011), it was preferred as the instrument for gathering data on the perceptions of mothers who have children with special needs regarding inclusive education. The data collected from the interviews conducted with the mothers was analyzed with content analysis, a qualitative data analysis method.

The interview is purposeful conversation and takes place generally between two people where one tries to obtain information from the other. There are three types of interview techniques; namely structured interview, semi-structured interview and unstructured interview. In this study, the semi-structured interview technique was employed. The semi-structured interview is an intermediate technique between structured and unstructured interviews and is the most commonly used interview technique (Karasar, 2002; Yildirim \& Simsek, 2011).

\subsection{Participant (Subject) Characteristics}

The study group comprised 11 mothers who had children with special needs attending the third, fourth and fifth grades in inclusive elementary schools in Edirne city center. The mothers participating in the study were selected with the criterion sampling method, which is a purposeful sampling method. The criterion sampling method involves studying all cases that meet a series of predetermined criteria. The criterion or criteria mentioned herein could be developed by the researcher or a prearranged list of criteria could be used (Yildirim \& Simsek, 2011). The criteria used to select the study group in this study were having a child with special needs attending the third, fourth and fifth grades of inclusive elementary schools and voluntary participation. Four of the mothers participating in the study were aged 26-35, while six were aged 36-45 and one was aged 46 and over. One mother was illiterate, whereas six mothers were elementary school graduates, three mothers were secondary school graduates and one mother was a university graduate. Eight mothers were housewives, one was a worker, one was a pensioner and one mother was a teacher. Three of the mothers had 1 child, while five mothers had 2-3 children and three mothers had 4 or more. Four families did not have social security, whereas six families had state social security from the Social Security Institution and one had a Green Card. There were no other members with special needs in any of the families. 


\subsection{Sampling Procedures}

"The Semi-Structured Interview Form for the Opinions of Mothers of Children with Special Needs Regarding Inclusive Practice (Appendix 1)" developed by the researchers for data collection purposes was used in the study. The first section of the form consisting of two sections comprises questions on the mothers' age, educational attainment, occupation and whether there were other people with special needs in the family. The second section of the interview form includes eight questions addressed to the participants during the semi-structured interviews.

In order to ensure content validity of the Interview Form, the questions in the Interview Form were reviewed by two professors working in the field of child development, an assessment and evaluation expert and a statistician. The questions submitted for expert debriefing were evaluated by the experts as suitable, partially suitable or unsuitable with respect to the aim of the study and the clarity of the questions. The questions deemed suitable by the experts were used as is, whereas the questions the experts deemed partially suitable were amended according to their suggestions. None of the questions were deemed unsuitable by the majority of the experts; therefore, there were no questions that were excluded from the forms. The Interview Form comprised of 8 questions was prepared for implementation in accordance with the opinions expressed within the Expert Information Form (Appendix 1).

The research data was collected in April-May of 2012 through semi-structured interviews conducted with the mothers of children with special needs attending inclusive elementary schools in the Edirne province. All interviews were conducted by the researchers at the schools the children attended, in quiet rooms and at their convenience. Prior to the interviews, the researchers briefly explained the aim of the study to the participating mothers; then asked the questions in the form to the participants and recorded their answers with their consent. During the interviews, the names of the participants were used; however, thereafter each participant was designated with a code as M1, M2, ... M11. Data collection took approximately 30 minutes. Following the completion of data collection, the researchers analyzed the study data using content analysis, which is a qualitative data analysis method (Yildirim \& Simsek, 2011).

Afterwards, the mothers' replies were reviewed and the information gathered was combined, organized and interpreted within the framework of the themes developed for the meaning of inclusion, similarities and differences, disability groups, suggestions on inclusive practice, adjustments in the educational environment and suggestions, required support types, the problems experienced in inclusion and solution suggestions. In the study, direct quotes were included and the results were interpreted on the basis of these direct quotes as, in qualitative studies, directly using and interpreting the results based on what was obtained from the interviewees is important for ensuring the validity of the research Yildirim \& Simsek, 2011).

\section{Results}

The results of the study carried out to determine the opinions of mothers who have children with special needs regarding inclusive education are presented below in line with the questions in the interview form.

\section{Meaning of Inclusion}

The question "In your opinion, what is inclusion?" was asked in order to understand what inclusion meant for the mothers who had children with special needs. Four mothers participating in the study said the child's circle of friends, three mothers said support for the child, one mother said the child's condition, another mother said the difference between a normal child and a child who has problems, and two mothers said they did not know anything about the subject.

M8 stated her opinion on the subject as "Friendship, circle of friends," while M5 said "Support for the child; his/her being better in his/her lessons; improvement in his/her behavior," M11 said "It eliminates the difficulty of failing the class. The teacher acts more consciously," and M9 said "It represents the difference between a normal child and a child who has problems."

\section{Similarities and Differences}

The mothers were asked which characteristics of their children were similar to and different from their classmates. Four of the mothers stated they were physically and behaviorally similar. One of these mothers, M5, said "They are similar in appearance and behavior," and M1 expressed her opinion as "He behaves almost the same as others, he has the same behavior as a normal child."

Three of the mothers stated they were similar in their manners of speech and the games they played, one mother said they were similarly adjusted and two of the mothers said they were similar in every aspect, whereas another mother said they were not similar. One of these mothers, M2, said "My son's friends are active like him. Their manners of speech and playing are the same," whereas M6 said "She is a child, too; like the others."

With respect to the differences among the children attending inclusive education, mothers generally stressed academic 
achievement. Three of the mothers stated their children had difficulty reading, two of the mothers said they were absentminded and one mother said they had problems with comprehension. M8 expressed her opinion on the subject as "He has difficulty reading; he cannot read, understand and solve. He is absentminded and has problems with comprehension."

Three mothers indicated hyperactivity and attention deficit as the cause of the difference, two mothers said experiencing limitation in movement, one mother said having difficulty in following the rules and one mother said deficiency in fine motor skills. One of the mothers stated that there was no difference. M2 expressed her opinions on the subject as "He can't focus on the lesson and can't pay attention. Attention deficit," and M1 as "Physically different. He can't behave in the same manner and can't act on his own."

\section{Disability Groups}

The mothers were asked which disability groups could benefit from inclusive practice and the reasons why. Seven mothers said students with orthopedic impairments, four mothers said those with learning disabilities, two mothers said those with mental disabilities, two mothers said those with hearing disabilities and another two said all disability groups could benefit from inclusion. One of the mothers stated none of the disability groups could benefit from inclusion. The mothers expressed their opinions on the subject and the reasons as follows:

M3 "Students with physical disabilities could attend. There is nothing wrong with their minds, they can understand. That is why they could attend;" M11 "Students with learning disabilities could benefit. They are normal children in the first place; there is no need to send them to other schools because they are slow to learn or have difficulty in learning;" M1 "All disability groups, whether or not they can communicate, could benefit because they could learn new behaviors from their peers. Both children with disabilities and normal children would benefit; they would learn how to behave in public and normal children would learn how to communicate with them."

\section{Suggestions on Inclusive Education}

For successful inclusion, six mothers suggested the provision of special educational support, two mothers suggested the questions asked and answers given be suitable for children's level, two mothers suggested the provision of financial support, one mother suggested that children should participate in more activities for their socialization, one mother suggested improving their fine motor skills, one mother suggested decreasing the class size and another suggested the provision of specialist support to teachers.

On the subject, M10 said "Extracurricular classes should be given to children with problems by special educators. Those who are suitable should be gathered in the schools they are attending to be given extracurricular educational support by special educators," and M1 said "Specialist support for teachers," stressing educational support. Whereas, M2 said "Questions suitable to the child's level should be asked without other children knowing or noticing," and M3 said "There aren't any books at this school Can could read. He cannot read because the writing is so small. The material should be suitable for the child," emphasizing the need to make adjustments according to the child. In addition, A9 stressed the importance of social activities by saying "Social activities. For example; the children should be able to go swimming or outdoors. The children could be instructed on the subject. They should be encouraged to carry out social activities outside the school."

\section{Adjustments in the Educational Environment and Suggestions}

The mothers were queried about the adjustments the teachers made in the educational environment. Four mothers participating in the study stated that the homework the teachers gave were suitable for the child's level. One of these mothers, M11, expressed her opinion as "By talking to the teacher of the first grade students, the teacher gives homework and instructs them in classes suitable for their level." In addition, four mothers mentioned seating arrangements. On the subject, M1 said "As the problem is physical, the teacher prepared an environment for him to sit comfortably. The teacher sat him at the front so that he could move more comfortably and be kept an eye on, ensuring his safety." One mother stated that the teacher attracted the child's attention by making eye contact, another said the teacher gave private lessons to the child in the classroom, a third said the teacher sat one student each week next to the child to provide assistance and another mentioned the teacher forming a group of successful students in the class. Furthermore, four of the mothers said the teacher made no adjustments and one mother said she did not know.

The mothers were requested to provide suggestions as to the adjustments in the educational environment. Seven of the mothers interviewed said they did not know. Whereas, M2 expressed her opinion as "I would like the teacher to be more tolerant with the grades. I want the teacher to encourage, force the child into many beneficial activities," M8 as "The homework that the teacher gives should be suitable for him, like normal children," and M10 as "The teacher formed a group consisting of successful students, but I would want these children to be distributed to other groups so that they can be motivated." 


\section{Required Support Types}

The mothers were queried about the types of support they required in inclusive education. Five of the mothers said they needed individualized education, three mothers said teachers, two mothers said special education, while two mothers said they required financial support, one mother said psychological support and another said support of the school administration. One mother said she did not require support.

M2 said "Private lessons could be provided at the school at separate times for the lessons they need help with," M10 said "I need the classroom teacher's support. I would like to speak more often with the teacher. I can only have a quick word when I come to talk. I need closer support from the classroom teacher," and M3 said "I need the special education teacher's support at the special education center. At the school, I need assistance with the lessons and the homework," mentioning individualized educational support. M9 and M7 who said they required financial support expressed their opinions as "Financial support. It is not sufficient. More financial support for the treatment costs."

\section{Problems Experienced in Inclusive Practice and Solution Suggestions}

The mothers were inquired about the problems they experienced in inclusive education. The mothers stated they experienced issues with the lessons, enrolling the child to the school and the class, and transportation to and from the school. Five of the mothers said they did not experience any problems.

M10 expressed her opinion on the subject as "My child's being unable to benefit much from the education provided. She is lost in the shuffle," and M9 as "Exclusion of the child by the teacher and the school management, and not being accepted to the school." M1 pointed out the transportation issue by saying "The transportation of the child to and from the school is the most important problem."

When the mothers were requested to provide suggestions for the problems they experienced, four of the mothers suggested that the teachers should act more responsibly while two mothers suggested that the families should act more responsibly. One of the mothers said enrollment of the child to the school should be legally ensured and another recommended the provision of special education training to the teachers. The five mothers who said they did not experience any problems did not offer any suggestions.

On the subject, M8 said "The teacher could show more understanding," M9 said "Instructors and families should act more responsibly. The families of normal children should provide proper guidance to their children to be more understanding to the others," M10 said "The classroom teacher should be knowledgeable about special education," M1 said "The child's acceptance to the school during enrollment is completely left to the individual's perspective. A legal solution could be provided."

\section{Discussion and Conclusion}

Upon inspection of the mothers' statements on the meaning of inclusion, it is apparent that the mothers are not able to explain inclusion accurately and that their knowledge on the subject is insufficient. However, inclusive education is defined as placing children with disabilities to regular or general education classes for instruction by providing appropriate support (Lerner, 2000). This might be due to the mothers' lack of knowledge. During the interviews, the mothers stated that they had no knowledge on the subject. One of the mothers, M4, expressed her lack of knowledge as "I don't know." Furthermore, in their study, Kargin, et al. (2003) revealed that parents' knowledge and skills concerning inclusion were limited.

Upon investigation of the mothers' opinions regarding the similarities between the children with special needs and normally developing children participating in inclusive education; the mothers said they were similar in physical appearance, speech, behavior and the games they played, while two mothers said they were similar in all aspects. Only one mother stated they had no similar characteristics. These statements show that mothers focus more on the similar characteristics of the children. Focusing on the similar characteristics will reveal that children with special needs have more similarities with normally developing children than differences. In this respect, great responsibility lies with the classroom teachers and specialists (Akcamete, 2010) as common interests provide a common ground and meeting place that allows them to spend time together. In their study with mothers of normally developing children, Oncul and Batu (2005) found similar results. Most of the mothers participating in the study said the special needs child was similar to their own children. However, the mothers were mostly enunciative of the similarity in the physical appearance of their children and the child with special needs.

Upon investigation of the mothers' opinions regarding the differences between the children with special needs and normally developing children in inclusive education; some mothers said they were academically different while some stressed the difference in behavior. There is a tendency to focus on the differences of children with disabilities from normally developing children rather than their similarities. This is due to the impact of some types of disabilities on learning (Akcamete, 2010). This difference of opinion among the teachers might be attributed to the type of disability of 
the children with special needs in their classes and, consequently, the impact of the type of disability on learning.

The mothers had varying opinions on the disability groups that could benefit from inclusion. Most of the mothers ( 7 mothers) said students with orthopedic impairments, four mothers said those with learning disabilities, two mothers said those with mental disabilities, two mothers said those with hearing disabilities and two mothers said all disability groups could benefit from inclusive education. This might be attributed to the greater focus on the degree of the disability rather than its type. Similarly, in the study carried out by Oncul and Batu (2005), the mothers of normally developing children said all disability groups could benefit from inclusive education. In the same study, mothers stated that children with special needs who had mild disabilities could benefit from inclusive education. Furthermore, various studies reported that children's types of disability did not appear as a factor affecting parents' opinions on inclusion (Gupta \& Buwade, 2013; Dimitrios et al., 2008). However, another study reported that the type of disability influenced parental opinion regarding the ideal educational placement for the child (Kasari, et al., 1999). The results of another study showed that the children who did not have a priority to be accepted to inclusive classrooms were the ones who required the most resources (Kniveton, 2004).

Mothers made various suggestions for achieving successful of inclusion. They suggested the provision of special educational support, the questions asked and answers given be suitable for children's level, the provision of financial support, organizing a greater number of activities for children's socialization, improvement of their fine motor skills, decreasing the class size and the provision of specialist support to teachers. The majority of the suggestions were mainly on educational support services. This is due to the fact that inclusion is a process that can only be properly implemented if educational support services are provided for the child with special needs and the teacher (Batu, 2000). Two or more people collaborate in educational support services. The education of individuals with special needs, once regarded as the field of special education, is now considered to be a shared responsibility requiring team work. Mainly instructors, other professionals, communication between families, cooperation, harmony and support quality are significant in effective inclusion (Salend, 1998). Another study indicated that parents' experience of parent-school collaboration was an important factor affecting parents' opinions of the school (Elbaum, et al., 2016).

Mothers' statements showed that the adjustments the teachers made in the educational environment for inclusion varied. On the other hand, four mothers said the teacher did not make any adjustments and one said she did not know. Four of the mothers, who stated the teacher made adjustments in the educational environment, said the teacher gave homework suitable to the child's level, four mothers said the teacher made seating adjustments, one mother said the teacher attracted the child's attention by making eye contact, one mother said the teacher gave private lessons and another said the teacher formed a group of successful students. The teachers apparently did not make adjustments such as ensuring the accessibility of material, organizing the classroom climate and forming study groups. Furthermore, the changes the teachers made mainly included adjustments concerning the aim, method and presentation of the content. The researchers believe that the teachers failed to adjust the educational environment according to the needs of the child because the teachers were not knowledgeable about, or had limited knowledge of, the requirements of children with special needs and inclusion. In the study conducted by Underwood (2010), the parents stated that the school failed to entirely meet their children's needs. Various studies have similarly reported that teachers mostly paid attention to seating adjustments and did not make any adjustments for other problems (Kargin et al., 2003; Sarac \& Colak, 2012; Vural \& Yikmis, 2008).

The majority of the mothers emphasized the need for educational support for their children, followed by psychological support and administrative support. One mother said she did not require any support. However, the study conducted by Hamedoglu and Gungor (2013) revealed that school resources were inadequate for children with special needs. Another study showed that family attitudes toward the quality of educational services was negative (Ahuja \& Sunish, 2013). However, appropriate resources and support must be provided for successful inclusion (Lerner, 2000). Provision of such services is the responsibility of the team. The education of individuals with special needs, once regarded as the field of special education, is now considered to be a shared responsibility requiring team work. Mainly instructors, other professionals, communication between families, cooperation, harmony and support quality are significant in effective inclusion (Salend, 1998).

The most important problems mothers experienced in inclusive education were problems concerning lessons, child's enrollment and transportation issues. The problems the children had with their lessons could be a result of the teachers' failure to make adjustments suitable to the characteristics and needs of all the children during instruction. Kargin et al. (2003) found similar results in their study carried out with teachers, school managers and parents. They reported that the majority of school managers did not have adequate knowledge of inclusion and that the environment, teacher and other children were not readied for inclusive education before the child with special needs joined the class. However, inclusion can only be successful by making the necessary adjustments in normal educational environments and providing a full range of support services. Another issue the mothers experienced in inclusion was rejection of the child. 
The studies carried out by Gupta and Buwade (2013) and Ahuja and Sunish (2013) show that mothers were concerned that their children would not be socially accepted by their peers without special needs. This situation could be due to the fact that neither normally developing children nor children with special needs were readied for inclusive practice. Normally developing children should be informed about the child with special needs, thus facilitating the acceptance of child with special needs (Batu, 2000). Furthermore, studies have shown that informing normally developing children about the child with special needs increased the social acceptance of children with special needs (Aktas \& Kucuker, 2002; Sahbaz, 2007). Another problem the mothers encountered was the transportation of the child. Children with special needs generally require support services when placed in general education classrooms. The provision of such services is the responsibility of the team. The members of the team change with the requirements of the parents and instructors (Salend, 1998).

The solution suggestions offered by the mothers were training the teacher on the subject of special education, the teachers and families acting more responsibly and legally ensuring the child's enrollment to the school. Gasteiger-Klicpera et al. (2013) reported that most of the parents of children in inclusive classrooms were more satisfied with the schooling of their children than the parents of children in special education schools. Mothers struggle for the placement of their children into general education classrooms so that they can have the same experiences and opportunities as other children and be raised as independent and contributing members of society. The study revealed that the mothers were not adequately knowledgeable about the subject of inclusion, that they focused on the similarities between the children rather than the differences, that there were different opinions on the disability groups which could benefit from inclusive practice, that the suggestions for achieving successful inclusion emphasized educational support services, that they required educational support during inclusive practice, and that the most significant problems they encountered were about the lessons, acceptance of the child and transportation.

In view of the study results, the researchers would like to make the following suggestions:

Mothers who have children with special needs could be informed about inclusion and inclusive education prior to implementation by organizing interactive meetings.

Special educational support services such as resource rooms, in-class assistance and special education counseling could be provided to both teachers and children with special needs at inclusive schools.

The opinions of mothers who have children with special needs regarding inclusion could be identified using mixed research models combining both qualitative and quantitative perspectives, or qualitative research methods in which more than one data collection method is utilized.

\section{References}

Ahuja, G., \& Sunish, T. V. (2013). Parent's attitude towards the inclusion of their children with autism in mainstream classrooms. Conflux Journal of Education, 1(2), 13-18.

Akçamete, A. G. (2010). Özel gereksinimi olan çocuklar. A. G. Akçamete (Ed.), Genel eğitim okullarında özel gereksinimi olan öğrenciler ve özel eğitim, 31-76. Ankara: Kök Yayıncılık.

Aktaş, C., \& Küçüker, S. (2002). Bilişsel-duyuşsal odaklı bir programın ilköğretim öğrencilerinin fiziksel engelli yaşıtlarına yönelik sosyal kabul düzeylerine etkisinin incelenmesi. Ankara Üniversitesi Eğitim Bilimleri Fakültesi Özel Ĕ̈itim Dergisi, 3(2), 15-25.

Batu, E. S. (2000). Kaynaştırma, destek hizmetler ve kaynaştırma hazırlık etkinlikleri. Özel Eğitim Dergisi, 2(4), 35-45. http://dx.doi.org/10.1501/ozlegt_0000000050

Ben-Yehuda, S., Leyser, Y. \& Last, U. (2010). Teacher educational beliefs and sociometric status of special educational needs (SEN) students in inclusive classrooms. International Journal of Inclusive Education, 14(1), 17-30. http://dx.doi.org/10.1080/13603110802327339

Dimitrios, K., Georgia, V., Eleni, Z., \& Asterios, P. (2008). Parental attitudes regarding inclusion of children with disabilities in greek education settings. Electronic Journal for Inclusive Education, 2(3), 1-13.

Elbaum, B., Blatz, E. T., \& Rodriquez, R. J. (2016). Parents'experiences as predictors of state accountability measures of schools' facilitation of parent involvement. Remedial and Special Education, 37(1), 15-27. http://dx.doi.org/10.1177/0741932515581494

Elzein, H. L. (2009). Attitudes toward inclusion of children with special needs in regular schools (A case study from parents' perspective). Educational Research and Review, 4(4), 164-172.

Gasteiger-Klicpera, B., Klicpera, C., Gebhardt, M., \& Schwab, S. (2013). Attitudes and experiences of parents regarding inclusive and special school education for children with learning and intellectual disabilities. 
International Journal of Inclusive Education, 17(7), 663-681. http://dx.doi.org/10.1080/13603116.2012.706321

Gupta, P., \& Buwade, J. (2013). Parental attitude towards the inclusion education for their disabled children. Voice of Research, 2(3), 12-14.

Hamedoğlu, M. A., \& Güngör, H. (2013). Opinions of the parents and the principals on the attitudes of principals towards mainstream education. (sample of a country in west black sea region in Turkey). The Online Journal of Counseling and Education, 2(3), 33-35.

Karasar, N. (2002). Bilimsel araştırma yöntemi. Ankara: Nobel Yayıncılık

Kargın, T., Acarlar, F., \& Sucuoğlu, B. (2003). Öğretmen, yönetici ve anne babaların kaynaştırma uygulamalarına ilişkin görüşlerinin belirlenmesi. Özel Ĕgitim Dergisi, 4(2), 55-76.

Kasari, C., Freeman, S. F. N., Bauminger, N., \& Alkin, M. C. (1999). Parental perspectives on inclusion: Effects of autism and down syndrome. Journal of Autism and Developmental Disorders, 29(4), 297-305. http://dx.doi.org/10.1023/A:1022159302571

Kniveton, B. H. (2004). A study of perceptions that significant others hold of the inclusion of children with diffucilties in mainstream classes. Educational Studies, 30(3), 331-343. http://dx.doi.org/10.1080/0305569042000224260

Lerner, J. W. (2000). Learning disabilities. Boston: Houghton Mifflin Company.

Liewellyn, A. (2000). Perceptions of mainstreaming: a systems approach. Developmental Medicine \& Child Neurology, 42, 106-115. http://dx.doi.org/10.1017/S0012162200000219

Öncül, N., \& Batu, E. S. (2005). Normal gelişim gösteren çocuk annelerinin kaynaştırma uygulamasına ilkin görüşleri. Ankara Üniversitesi Eğitim Bilimleri Fakültesi Özel Eğitim Dergisi, 6(2), 37-54. http://dx.doi.org/10.1501/Ozlegt_0000000090

Şahbaz, Ü. (2007). Normal öğrencilerin kaynaştırma sınıflarına devam eden engelli öğrenciler hakkında bilgilendirilmelerinin engellilerin sosyal kabul düzeylerine etkisi. Eurasian Journal of Educational Research, 26, 1999-208.

Salend, S. J. (1998). Effective mainstreaming. New Jersey: Prentice- Hall Inc.

Saraç, T., \& Çolak, A. (2012). Kaynaştırma uygulamaları sürecinde ilköğretim sınıf öğretmenlerinin karşılaştıkları sorunlara ilişkin görüş ve önerileri. Mersin Üniversitesi Eğitim Fakültesi Dergisi, 8(1), 13-28.

Underwood, K. (2010). Involving and engaging parents of children with individual education plans. Exceptionality Education International, 20(1), 18-36.

Vural, M., \& Yıkmış, A. (2008). Kaynaştırma sınıf öğretmenlerinin öğretimin uyarlanmasına ilişkin yaptıkları çalışmaların belirlenmesi. Abant İzet Baysal Ĕgitim Fakültesi Dergisi, 8(2), 141-159.

Yıldırım, A., \& Şimşek, H. (2011). Sosyal bilimlerde nitel araştırma yöntemleri. (8. Basım). Ankara: Seçkin Yayıncılık San. Ve Tic. A. Ş.

\section{Appendix 1}

\section{Interview Questions}

1. In your opinion, what is inclusion?

2. What are the similarities between your child and his/her classmates?

3. What are the differences between your child and his/her classmates?

4. Children in which disability group could benefit from inclusion? Please explain the reasons.

5. What could be done to achieve successful inclusion?

6. What kind of adjustments could be made in educational environments for inclusion? What kind of adjustments did the teacher make in your child's class?

7. What type of support do you require in inclusive education? Which support type do you think is more beneficial?

8. What are the most important problems encountered in inclusive education? What can be done to solve these problems?

\section{$(\mathrm{cc}) \mathrm{BY}$}

This work is licensed under a Creative Commons Attribution 3.0 License. 